\title{
Methodological tools to ensure economic security in the personnel management system of enterprises
}

\author{
Guzaliya Klychova ${ }^{l}$, Alsou Zakirova, ${ }^{l, *}$, Angelina Dyatlova ${ }^{2}$, Aigul Klychova ${ }^{l}$, Evgenia \\ Zaugarova $^{3}$, and Nailya Zalyalova ${ }^{1}$ \\ ${ }^{1}$ Kazan State Agrarian University, 420015, Kazan, Russia \\ ${ }^{2}$ Moscow University of the Ministry of Internal Affairs of the Russian Federation named after V. Kikot, \\ 117997, Moscow, Russia \\ ${ }^{3}$ Saint Petersburg State University of Economics, 191023, Saint Petersburg, Russia
}

\begin{abstract}
Economic security of the enterprise is designed to ensure stable and continuous functioning of the economic entity. The study of the state of economic security is one of the key factors for enterprises, as the level of its security depends on the financial condition. The purpose of personnel management in the system of economic security of the enterprise is to find ways to minimize risks and threats to employees. Ensuring economic security is one of the most important problems faced by enterprises. The overall system of integrated enterprise management is closely related to security and personnel management. The article examines the main threats and factors affecting economic security, as well as measures to improve the system of protection of the organization, the factors affecting the external and internal environment, measures for the organization of economic security in the enterprise, developed a methodology for assessing the personnel management system to make effective management decisions.
\end{abstract}

\section{Introduction}

Today, the interest in the economic security of enterprises is increasing every day. This topic is the basis for many scientific publications, works, articles from Economics to information systems. This indicates that the concept of "security" is a popular and highly necessary system of existing measures to ensure the safety of financial and economic activities of the enterprise [1].

In order to determine the state of economic security, it is necessary, first, to understand its essence. For example, many authors tend to believe that " economic security is a state of protection of vital interests of the enterprise from internal and external threats."

But a more precise definition, in our opinion, is - "the Economic security of the enterprise - a state of its protection from the negative impact of internal and external

*Corresponding author: zakirovaar@mail.ru 
threats, destabilizing factors, which ensures sustainable implementation of the main commercial interests and objectives of the statutory activities" [2].

Security is a polysemantic concept that characterizes primarily the security and low level of risk for a person, society or any other subjects, objects or their systems [3]. By "safety "we mean"no danger".

The purpose of ensuring the economic security of the enterprise is to protect its property and employees from sources of external and internal security threats, to determine the causes and conditions that cause them.

To assess the impact of threats on the enterprise, it is necessary by analyzing the external and internal environment. For each enterprise, "external" and "internal" threats should be considered individually, depending on the industry, scale and scope of the enterprise. After analyzing the classification of economic threats of the enterprise on the external and internal environment, we have identified categories that include elements that are acceptable to almost any economic entity (Fig.1).[4].

The external environment is the conditions and factors that arise independently of the activities of the enterprise and have a significant impact on it. It is impossible to exclude the influence of environmental factors on the state of the organization as a whole, but their analysis allows the organization to actively participate in the prevention of threats and the formation of additional opportunities. It should be noted that all these factors are closely interrelated and changes in one area will inevitably lead to changes in another and their analysis should not be carried out separately, but in a complex [5].

The internal environment includes persons who directly carry out activities in the organization and are amenable to control influence from the organization (Fig.1). All these factors should be seriously examined in the process of analyzing the internal environment of the organization. Of particular importance in the analysis of the internal environment for strategic management is that it determines not only the relationship with colleagues in the organization, but also how the company interacts with the external environment.

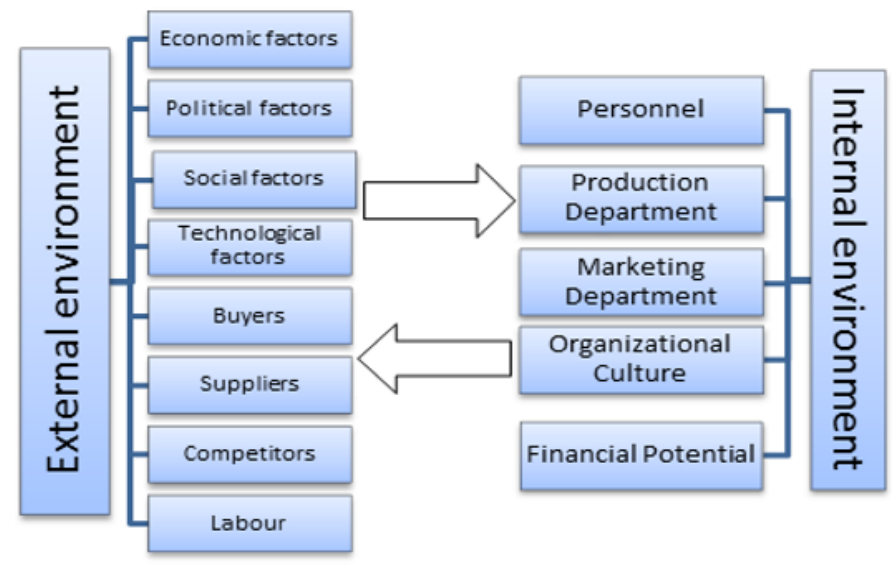

Fig. 1. Factors affecting the external and internal environment

Today, not all business leaders are ready to fully assess the need to create a reliable system of economic security.

The system of economic security of the enterprise and the mechanism of its ensuring depend not only on specially created divisions, but also on the positions assigned to the head of structural division concerning safety. Therefore, the main role in ensuring the 
economic security of the enterprise belongs to its personnel, human potential, which is the main resource of the enterprise[6].

\section{Materials and Methods}

The method of maintaining the economic security of the enterprise is based on a set of measures and organizational measures for its implementation and monitoring, which allow to achieve the highest level of economic security.

Measures for the organization of economic security at the enterprise:

1. Prediction. Analysis of the external and internal environment, i.e. analysis of the degree of protection of various structures of the enterprise and prediction of possible threats or damage.

2. Immediate response. Identification of the causes of threats and their possible further recurrence.

3. Planning. Development of measures for compensation of damage and measures to eliminate relapses [7].

In order for an enterprise to successfully exist in the future, it must successfully predict the external environment and identify possible threats that may befall the enterprise in the future.

To achieve this goal, the system of economic security must perform a number of functions:

1. administrative and managerial functions. These include the definition of the rights, obligations, persons responsible for security issues, the implementation of representative functions of the enterprise in this area;

2. economic and administrative function involves control over the resources necessary to address the economic and administrative tasks of ensuring the safety of the enterprise, training and management aimed at preserving its property;

3. accounting and control function. Accounting and control determine the activities to be protected, as well as possible factors of financial instability and instability of the enterprise, and assess the sources of their occurrence;

4. organizational and technical function is to create the organizational structure of the security system and the organization of interaction between the individual structural units;

5. planning and production function contributes to the development of comprehensive programs to ensure the safety of the enterprise;

6. logistics function involves the provision of special equipment security system;

7. scientific and methodological function contributes to the accumulation and dissemination of experience in the field of security, as well as the organization of training of employees of the Department;

8. information and analytical function involves the collection, accumulation, processing of data related to security, the creation of the necessary technical and methodological tools, as well as their use $[7,8]$.

The task of the company's management is to regularly analyze and build the optimal capital structure to ensure financial stability, solvency and financial independence of the enterprise. However, the main factor of economic security is the personnel of the enterprise. A professional team of managers can lead a loss-making company to the top or, conversely, illiterate management, neglect of duties and lack of labor discipline can lead a profitable enterprise to bankruptcy. The main direction of the personnel policy of the enterprise, both in quantitative and qualitative terms, should determine the need for labor, be its form of treatment and use [9]. 
When taking on a job you need to pay attention to such quality indicators as: debt, rent arrears, having children, and alimony, criminal records, administrative offense, high selfesteem during the interview and the ability of the material to confirm this self-assessment, data from the debtors bailiffs, the presence of accidents, etc.

For optimal management of employees, the economic security service is desirable at least once a year to conduct a SWOT and STEP-analysis of the enterprise, focusing on finding out what threats and what opportunities are fraught with the external environment. Strengths and weaknesses of the internal environment of the organization as well as threats and opportunities determine the conditions for the successful existence of the organization. Therefore, personnel services and management in general, when analyzing the internal environment, are interested in what strengths and weaknesses accurately identify individual components of the organization and the organization as a whole (Table.1, 2). In order to successfully survive in the long run, an organization must be able to predict what opportunities may open up for it. To understand how to lead a team and what employees expect from the conditions and tasks set by them, this analysis is carried out. That is, it is necessary to make it clear to employees that the organization is interested in their opinion, trying to improve their motivation, productivity and quality of work.

Table 1. SWOT - analysis of the enterprise to ensure economic security in the personnel management system

\begin{tabular}{|c|c|}
\hline Internal environment & External environment \\
\hline $\begin{array}{c}\text { Strength } \\
\text { sustainable financial position of the } \\
\text { organization; } \\
\text { young team; } \\
\text { good business reputation; } \\
\text { prospects of development at the enterprise; } \\
\text { incentives and incentives; } \\
\text { competence of the managers; } \\
\text { convenient location of the organization }\end{array}$ & $\begin{array}{c}\text { Scope } \\
\text { cooperation with universities to improve } \\
\text { skills; } \\
\text { introduce new technologies; } \\
\text { recruitment and training of new employees }\end{array}$ \\
\hline $\begin{array}{c}\text { Weakness } \\
\text { high staff turnover; } \\
\text { stressful working conditions; } \\
\text { there is no automated accounting of } \\
\text { certification information; } \\
\text { no responsible / consultant for the progress of } \\
\text { employees ' activities }\end{array}$ & $\begin{array}{c}\text { Threats } \\
\text { mastering new technologies; } \\
\text { limited human resources in the labour market; } \\
\text { influence of personal qualities of the employee } \\
\text { on performance of work/tasks; } \\
\text { the possibility of leakage of information by } \\
\text { unscrupulous employees }\end{array}$ \\
\hline
\end{tabular}


Table 2. STEP - analysis of the enterprise to ensure economic security in the personnel management system.

\begin{tabular}{|c|c|}
\hline Social factors & Technological factors \\
\hline $\begin{array}{l}\text { employee's attitude to work and rest; } \\
\text { attitude to quality of life; } \\
\text { level of education; } \\
\text { influence of surrounding factors on a person; } \\
\text { collective; } \\
\text { stimulations; } \\
\text { the solution of demographic problems; } \\
\text { social insurance; } \\
\text { attitude to health }\end{array}$ & $\begin{array}{l}\text { development of science and technology; } \\
\text { R \&D financing; } \\
\text { grants and patents; } \\
\text { modernization and improvement of products; } \\
\text { improve working conditions; } \\
\text { communication tools; } \\
\text { business reputation }\end{array}$ \\
\hline Economic factors & Political factors \\
\hline $\begin{array}{c}\text { wage level; } \\
\text { awards and incentives; } \\
\text { prospects for increasing demand; } \\
\text { taxation; } \\
\text { the prospects of the industry; } \\
\text { rate of inflation; } \\
\text { seasonality; } \\
\text { career prospects }\end{array}$ & $\begin{array}{c}\text { russian legislation; } \\
\text { changes in legislation, laws and other } \\
\text { regulations; } \\
\text { political situation in the Russian and } \\
\text { international markets; } \\
\text { enterprise policy; } \\
\text { regulatory authorities and regulations; } \\
\text { tax policy }\end{array}$ \\
\hline
\end{tabular}

Also, for more productive work in the enterprise, the personnel department and line managers in addition to job descriptions, standards and regulations of work performed and other things, it is necessary to introduce as a working document, sample test tasks for employees that will help in the development of criteria for assessing the efficiency of personnel.

The list of quality indicators by which a potential applicant for a particular position is evaluated in each organization is individual, and depends on who the heads of enterprises want to see in this position.

In modern conditions of management in all large organizations are usually created Autonomous security services, and the safety of small firms can be provided by territorial (district or city) services, in which the firm employs one or more security guards. Such security services are usually established under the local internal affairs bodies or the state security service [10].

The security service at the enterprise should be prepared for the occurrence and/or prevention of a dangerous situation that may arise due to a conflict of business interests.

It is expedient to create a separate service of economic security of the enterprise, which would direct the work of individual services and analyze the external and internal environment. Management should soberly assess their ability to create this service and its mission in the enterprise. Economic security of an enterprise consists of several functional components that have different priorities for each specific enterprise, depending on the nature of the threat[11].

Unfortunately, the reality is that enterprises, in particular the agro-industrial complex, pay little attention to the security system as a whole, not to mention the economic. Hiring unskilled workers, poor organization of the place of work, lack of proper protection of property, all this leads to losses (theft, fraud, unfair behavior on the part of employees).

Ensuring economic security is considered primarily as a "trade secret" of the organization, the protection of information and its intangible assets. To date, the concept of "economic security" has received a broader concept and it has already begun to include: the atmosphere of the team, the competence of employees, motivation to work, the human factor. The impact of these factors should not be underestimated, as they pose internal 
threats to enterprises. In turn, these threats can cause irreparable damage to the organization. These are, for example, intentional or unintentional actions/omissions of employees; leakage and loss of confidential information, trade secrets; undermining the business reputation of the organization, including in business circles; the emergence of problems in relations with partners and competitors, etc.as a rule, employees are concerned about the stability of the organization in the market, as this will depend on the stability of their wages. But if employees do not care about the stability of the organization, and they do not see any incentives to improve their financial situation (career growth, change of activities, etc.), they begin to illegally improve their financial situation[11, 12].

\section{Results}

The purpose of ensuring economic security in the process of personnel management is mainly to create a highly qualified team, motivation system, solving internal tactical problems.

Success of work of any enterprise is provided by the workers occupied on it. That is why the modern concept of enterprise management involves the allocation of a larger number of functional areas of management that is associated with the management of the personnel component of production - the personnel of the enterprise.

The initial stage in the process of personnel management - recruitment and selection. All subsequent actions in the personnel management process depend on how the selection is made and which employee is selected to work in the organization. Therefore, in order not to create additional difficulties, it is necessary to treat this stage with all seriousness. Personnel selection is a system of measures to attract exactly those people who meet the qualitative characteristics of the economic entity. Personnel management begins with attracting potential candidates [13, 14].

Poorly organized recruitment leads to undesirable consequences, such as staff turnover, bad atmosphere within the team, violations of discipline, etc.

In order to make it easier for personnel services, and most importantly for heads of enterprises, to make management decisions and manage the team, it is necessary to fully study it, to see the whole picture of the personnel potential. After all, as we have already understood, "frames decide everything." In this regard, the personnel services at the enterprises are invited to evaluate the personnel on the basis of qualitative and quantitative indicators. This can be done both in individual departments and throughout the enterprise as a whole.

To ensure economic security in the personnel management system, we propose to evaluate it using special questionnaires (Table.3, 4). 
Table 3. Enterprise personnel assessment test.

\begin{tabular}{|c|c|c|c|}
\hline № & Questions & Answer choice & Points \\
\hline \multirow[t]{8}{*}{1.} & Age & Under20 & 2 \\
\hline & & 20 to 24 & 4 \\
\hline & & 25 to 29 & 6 \\
\hline & & 30 to 34 & 7 \\
\hline & & 35 to 39 & 8 \\
\hline & & 40 to 44 & 5 \\
\hline & & 45 to 49 & 3 \\
\hline & & Over 50 & 1 \\
\hline \multirow[t]{3}{*}{2.} & Education & Higher professional education & 1 \\
\hline & & Secondary general education & 2 \\
\hline & & Secondary vocational education & 3 \\
\hline \multirow[t]{5}{*}{3.} & Experience & From 1 year & 1 \\
\hline & & 1 to 3 years & 2 \\
\hline & & 3 to 5 years & 3 \\
\hline & & 5 to 10 years & 4 \\
\hline & & More than 10 & 5 \\
\hline \multirow[t]{2}{*}{4.} & Experience in the specialty & Yes & 2 \\
\hline & & No & 1 \\
\hline \multirow[t]{3}{*}{5.} & Advanced training & On speciality & 3 \\
\hline & & Other educational programs & 2 \\
\hline & & No & 1 \\
\hline \multirow[t]{2}{*}{6.} & Chronic disease & Yes & 1 \\
\hline & & No & 2 \\
\hline \multirow[t]{2}{*}{7.} & Pernicious habits & Yes & 0 \\
\hline & & No & 1 \\
\hline \multirow[t]{2}{*}{8.} & Alimony & Yes & 0 \\
\hline & & No & 1 \\
\hline \multirow[t]{2}{*}{9.} & Criminal record & Yes & 0 \\
\hline & & No & 1 \\
\hline \multirow[t]{2}{*}{10.} & Rent or loan debts & Yes & 0 \\
\hline & & No & 1 \\
\hline \multirow[t]{2}{*}{11.} & Administrative offence & Yes & 0 \\
\hline & & No & 1 \\
\hline \multirow[t]{3}{*}{12.} & Absentee days to work & With good reason & 3 \\
\hline & & Without good reason & 1 \\
\hline & & Not to miss & 2 \\
\hline \multirow[t]{2}{*}{13.} & The presence of their own homes & Yes & 2 \\
\hline & & No & 1 \\
\hline \multirow[t]{2}{*}{14.} & The presence of the vehicle & Yes & 2 \\
\hline & & No & 1 \\
\hline \multirow[t]{4}{*}{15.} & Do You spend a lot of time on social media during & Yes & 1 \\
\hline & working hours (except for activities related to & No & 2 \\
\hline & professional necessity). & Rarely & 3 \\
\hline & & Work only & 4 \\
\hline \multirow[t]{3}{*}{16.} & Foreign languages skills & Don't know & 1 \\
\hline & & 1 to 3 & 2 \\
\hline & & More than 3 & 3 \\
\hline \multirow[t]{4}{*}{17.} & Knowledge of foreign languages & Don’t speak & 1 \\
\hline & & Elementary & 2 \\
\hline & & Intermediate & 3 \\
\hline & & Advanced & 4 \\
\hline \multirow[t]{2}{*}{18.} & $\begin{array}{l}\text { PC usage level (Word, Excel, Power Point, } \\
\end{array}$ & Basic & 1 \\
\hline & Photoshop, Internet) & Intermediate & 2 \\
\hline
\end{tabular}


Table 4. Assessment test of the enterprise personnel management system.

\begin{tabular}{|c|c|c|c|c|}
\hline \multirow[b]{2}{*}{ № } & \multirow[b]{2}{*}{ Question } & \multicolumn{3}{|c|}{ Answers } \\
\hline & & Yes & No & $\begin{array}{l}\text { Don't } \\
\text { know }\end{array}$ \\
\hline 1. & Are you satisfied with your position at this place of work? & & & \\
\hline 2. & Are you satisfied with your salary? & & & \\
\hline 3. & $\begin{array}{l}\text { The presence of trade unions that defend the interests of } \\
\text { employees to the employer }\end{array}$ & & & \\
\hline 4. & With the right offer, are you ready to quit your old job? & & & \\
\hline 5. & $\begin{array}{l}\text { Do you think that many important events in Your life were } \\
\text { related to work? }\end{array}$ & & & \\
\hline 6. & Is the paperwork carried out correctly by personnel services? & & & \\
\hline 7. & $\begin{array}{l}\text { Does the organization control the objective of the analysis } \\
\text { documentation, eliminating financial and other irregularities? }\end{array}$ & & & \\
\hline 8. & Is there control over the document flow for personnel records? & & & \\
\hline 9. & $\begin{array}{l}\text { Are you ready to undergo vocational training or professional } \\
\text { development, if it will help You in your career growth? }\end{array}$ & & & \\
\hline 10. & $\begin{array}{l}\text { Does the sequence of control approved by the organization, } \\
\text { reliability, timeliness, confidentiality, accuracy of registration of } \\
\text { information? }\end{array}$ & & & \\
\hline 11. & $\begin{array}{l}\text { Is there a general control of automated information systems in } \\
\text { the agricultural organization? }\end{array}$ & & & \\
\hline 12. & $\begin{array}{l}\text { Does this organization program control of economic and } \\
\text { financial operations? }\end{array}$ & & & \\
\hline 13. & $\begin{array}{l}\text { Does the organization determine the order of information } \\
\text { management? }\end{array}$ & & & \\
\hline 14. & Are job descriptions observed in the organization? & & & \\
\hline 15. & $\begin{array}{l}\text { Does the organization have a Provision for the protection of } \\
\text { personal data? }\end{array}$ & & & \\
\hline 16. & $\begin{array}{l}\text { Do You consent to the processing and transfer of your personal } \\
\text { data? }\end{array}$ & & & \\
\hline 17. & $\begin{array}{l}\text { Is it necessary to create a separate Economic Security service at } \\
\text { the enterprise, to control personal data, confidential information, } \\
\text { intangible assets, to prevent illegal actions of employees? }\end{array}$ & & & \\
\hline 18. & Are you satisfied with the work of the personnel service? & & & \\
\hline 19. & $\begin{array}{l}\text { Would You like to participate in tests or surveys to improve the } \\
\text { work of the HR Department? }\end{array}$ & & & \\
\hline 20. & $\begin{array}{l}\text { Would You like to participate in activities to strengthen the } \\
\text { workforce? }\end{array}$ & & & \\
\hline
\end{tabular}

Table 3 and 4 provide snippets of test questions that will help the employer better assess the employee and determine whether he poses a threat to the economic security of the organization.

The main personal characteristic of a potential applicant is age. Any selection of employees is based on age division. This figure should be scrutinized and updated in respect of the employees of successful and having high performance.

As a rule, most employers try to hire employees based on their level of education. The higher the education, the more preferable for employers will be the employment of the future employee, as employers strive for a high intellectual potential of the enterprise team. However, these indicators should be justified by achievements in work. The employer must examine the employee's education and provide appropriate employment.

Employers most often try to select employees with a level of experience above the average. Since they believe that if a person has worked in this position for a certain amount of time, then he is not afraid to do the same job and will do it at a high level.

As practice shows, business leaders often prefer middle-aged employees from 30 to 45 years, with higher education and with experience of at least 6 years.

One of the ways to determine the quality of the employee is his experience in the specialty and the availability of higher and secondary vocational education. 
The employer prefers to see a healthy employee without chronic diseases and bad habits at work, assuming the appropriate load or duties to the profession. Knowledge about the physical condition of the employee will help to avoid the organization of complaints about various compensations.

Another thing that is very important to pay attention to when assessing the staff is alimony, criminal record, administrative offenses, debts. All these indicators are extremely negative internal threats to economic security and can have serious consequences. How an employee feels about his or her work can be determined by his or her absences from work. If a person allowed himself to miss work often and without good reason, then such an employee will also be a threat to economic security because of his unreliability.

An employee's own housing usually implies a more stable social position, which excludes the possibility of additional earnings that affect his productivity and ability to work at the main place of work. An employee who has a vehicle is more mobile, can use personal transport for official purposes. The employee is not connected with social networks in his professional activities, and a lot of time devoted to them, is a negative factor in terms of his constant distraction from professional activities, and the possible disclosure of confidential information discredits the employee and the employer.

Language proficiency is considered a good advantage in staff selection. An employee who speaks several languages will be able to prove himself during foreign diplomacy: negotiations or business correspondence.

The level of knowledge of a personal computer largely affects how much time an employee spends performing each task. This is determined by their administrative competence. High level of PC proficiency means that the organization will not have material costs associated with training and elimination of intentional/unintentional errors on the part of employees.

If there are no relevant regulatory requirements for the quality indicators of the employee, they must be specified in the internal regulations on the basis of the average assessment of successful employees.

The information obtained during the analysis will be the basis for further planning of economic security in the personnel management system. In the future, the human resources Department or individual units will be easier to select potential candidates for a certain position. If the assessment of all these staff indicators is not taken into account or very little attention is paid to it, it can lead to personnel risks. And personnel risks are internal threats that directly affect economic security.

During the assessment, tests containing a list of questions that take into account the specifics of the work at the enterprise are filled in personified. When scoring answers to questions it is recommended to proceed from the following: Yes-3 points; do not know - 2; no, never -1 . The level of economic security in the personnel management system will be assessed by the formula:

$$
E=\left(\sum_{i=1}^{m} E_{P A} / \mathrm{m}+\sum_{j=1}^{n} E_{P M S} / \mathrm{n}\right) / 2
$$

where E-assessment of economic security in the personnel management system; $\mathrm{E}_{\mathrm{PA}}$ personnel assessment; $E_{P M S}$ - assessment of the personnel management system; $m$-the number of participants in the assessment; $n$-the number of participants in the assessment.

The final assessment of economic security indicators is recommended to be determined depending on the values of the indicators for both questionnaires on the basis of table 5 , which is the resulting methodology and describes the final result of the assessment[15]. 
Table5.Generalizing assessment of economic security in the personnel management system at the enterprise

\begin{tabular}{|c|c|c|c|c|}
\hline Quality level & High & Medium & Below average & Low \\
\hline Level value & $99-80$ & $79-55$ & $54-33$ & Less than 33 \\
\hline
\end{tabular}

Improving productivity can be seen as an impact through the system of motivation, increase staff income, as well as the financial stability of the organization.

The difficulty in ensuring the system of economic security is that its effectiveness is almost entirely dependent on the human factor. As a rule, even if there is a professional security chief in the organization, it is impossible to ensure that each employee understands the importance, importance and necessity of security measures.

The main measures of the system of economic security of any organization include:protection of the rights and interests of the company and its employees; study of partners, clients, competitors, candidates for work in the company; countering technical penetration for criminal purposes; detection, prevention and suppression of possible illegal and other negative activities of the company's employees to the detriment of its safety; ensuring the safety of material values and information constituting a trade secret of the enterprise; formation among the population and business partners of a favorable opinion about the company, contributing to the implementation of economic activity plans and statutory objectives; compensation for material and moral damage caused as a result of illegal actions of organizations and individuals;monitoring the effectiveness of the security system [16].

The system of economic security is built taking into account the listed methods of ensuring economic security, conditions of competitiveness and specifics of activity of the enterprise. The effectiveness of economic security in the organization depends on the existing legal framework, material, technical and financial resources of the organization, the understanding of employees of security issues in the organization, the availability of security services and other things.

\section{Discussion}

Not only strategy development, but also its implementation and coordination are important for effective economic security of the enterprise. Depending on the completeness of information that is the basis for developing the strategy and conditions for its implementation, plan the final strategy is significantly different. Therefore, it is important for specialists in economic security to think about how to organize the process of developing strategies, obtaining and analyzing information, making timely and informed management decisions[17]. The enterprise needs to identify interrelated activities and organize their management as a system. Regardless of the form of ownership, production and personnel, the main goal of economic security for each enterprise is to ensure stable and efficient functioning today and in the future. To achieve competitiveness of technological and technological potential of enterprises; protection of information resources; minimization of the threat to the environment from the production and economic activities of enterprises, the implementation of a high level of personnel and intellectual security of enterprises; effective protection of capital, tangible and intangible assets the main objectives of the organization which they are [18].

In business, competition is impossible without information. The desire to obtain confidential information inevitably leads to unfair competition.

To date, not all business leaders have a reliable system of economic security, especially due to the fact that these measures are expensive for the enterprise. 
Measures to ensure the safety of information in a single enterprise can be different in scale and form and depend on the production, financial and other capabilities of the enterprise, the quantity and quality of protected secrets. At the same time, the choice of such measures should be based on the principle of reasonable sufficiency, adhering to the "Golden mean" in financial calculations, and closure of redundant information.

With the growth of profits and the size of the enterprise, the security service will be allocated as an independent unit, the number of its employees will increase to several dozen, it will have several separate units that will fully perform the functions of economic intelligence, counterintelligence, information protection, monitoring, forecasting and modeling of the economic state, strategy development and optimization of management (crisis management). The economic security service should have sufficient resources to implement the chosen strategy and policy of the enterprise [19].

Management, for its part, needs to take into account that the organizational structure and skilled workforce have an undeniable impact on the efficiency of the use of personnel. If you regularly conduct training of employees, encourage staff to regular development and motivate to high-performance work on the part of each employee, it mainly contributes to the exclusion of the appearance of unreliable employees, as well as behavior that violates these standards. But, on the other hand, the organization, including managers, face the problem of investment, because to date there is insufficient investment in the development of the intangible sphere.

An essential condition for the success of the Corporation is to increase the funds allocated to work with the staff. Attracting investment in the selection and training of personnel becomes the main condition for gaining a stable position in the market. Increasing the productivity of personnel is possible only as a result of the application of fundamentally new approaches to working with personnel, and in particular with employees engaged in managerial work. New approaches to work with people are its complex nature, wider use of planning elements, the use of individual forms of work. The concept of "human resources" is based on the economic feasibility of investments related to the selection of personnel, training, identification of potential and abilities in employees, and the preservation of personnel in a working condition [20].

In the future, for effective personnel management and monitoring of economic security by individual services, we propose the creation of software based on the assessments and analysis.

In the presence of a large number of employees, it is important for the organization to automate the personnel management system, without large financial investments and minimizing economic threats from employees. This software will allow the company to: quickly make management decisions; manage the process of staffing; quickly respond to threats; monitor all stages of selection (recruitment, selection, hiring); manage training and professional development of employees; monitor compliance with regulations and job descriptions; control labor costs; monitor compliance with legal and legislative documents by employees.

\section{Conclusion}

Thus, having studied in detail the problems associated with economic security, we came to the following conclusions:

1. one of the goals of economic security is the ability to work with minimal losses and constantly develop in modern conditions of changes in the external and internal environment.;

2. the economic security of the organization is the most important anti-crisis element that supports the economic independence and security of our country; 
3. the state should support various forms of ownership, especially small and medium-sized enterprises, by adopting a law that promotes the formation and development of enterprises;

4. to ensure the security of the organization, security services are created in its structure, some of which are aimed at neutralizing internal and external threats to economic security [21].

5. The concept of economic security of the organization indicates that the organization is under the constant influence of internal and external factors. By predicting, neutralizing, adapting and reducing the impact of threats, it achieves its goal-to operate sustainably and effectively in the present and future. This achieves the main objective of the organization-to achieve profitability.

6. The factors that create threats to economic security include:

7. reduction of the level of implementation of the norms of legislative acts, weakening of public administration and control;

8. the growth of the scale and types of corruption in the economic and financial spheres, the spread of organized crime;

9. widening inequalities in regional development leading to economic imbalances.

In modern conditions, the organization must be able to adapt to changing environmental conditions, and for this it is necessary to have a well-established, able to optimally adapt to the projected future changes in the external environment of the structure of the organization. We can talk about the economic security of the organization as the security of the organization's interaction with the subjects of the external environment.

Ensuring economic security is an important and complex activity of the organization, without which it is impossible to understand its functions and development, and this goal is achieved through the effectiveness of the organization, legal support, financial stability, information security, protection of corporate secrets, property of the organization and other measures. At the same time, to ensure the economic security of the organization, it is necessary to work with minimal losses and develop in the modern conditions of constantly changing external and internal environment.

In General, the economic security of the enterprise is determined by the material, financial, human, technical potential of the enterprise and competitive advantages arising from the compliance of the organizational structure of its strategic goals and objectives.

\section{References}

1. HaiTao, Md Zakirul Alam Bhuiyan, Md Arafatur Rahman, FGCS 98, 660-671 (2019) https://doi.org/10.1016/j.future.2019.03.042

2. I. Koshkina, M. Sharamko, Procedia-SBS ,214, 858 - 865, (2015) https://doi.org/10.1016/j.sbspro.2015.11.741

3. M.R. Fazlida, Jamaliah Said, Proc. Econ. Fin., 28, 243-248 (2015) https://doi.org/10.1016/S2212-5671(15)01106-5

4. Nadine Niewöhnera, Laban Asmara, Fabio Wortmanna, Daniel Röltgena, CIRP, 84, 826-831, (2019) https://doi.org/10.1016/j.procir.2019.04.295

5. John R.S. Frasera, Betty J. Simkins, Bus. Horiz., 59, 689-698 (2016) https://doi.org/10.1016/j.bushor.2016.06.007

6. G.S. Klychova, B.G. Ziganshin, A.R. Zakirova, G.R. Valieva, A.S. Klychova, J. EAS, 12, 4958-4965 (2017) DOI: 10,3923 / jeasci.2017.4958.4965

7. Mohamed S.Saleha, Abdulkader Alfantookh, Appl. Comp. and Inf., 9, 107-118 (2011) https://doi.org/10.1016/j.aci.2011.05.002 
8. Mariuţa Şerbana, Raluca-Mariana Ştefanb, Eduard-Ionel Ionescuc, PEF, 16 288-292 (2014) https://doi.org/10.1016/S2212-5671(14)00803-X

9. Ivana Kolařováa, Pavel Žiaran, Procedia - SBS, 220, 184-190 (2016) https://doi.org/10.1016/j.sbspro.2016.05.483

10. Muthu Ramachandra, Inter. J. Inf. Manag., 36, 580-590 (2016) https://doi.org/10.1016/j.ijinfomgt.2016.03.008

11. Nicolas Anciauxab, Philippe Bonnetc, Luc Bouganimab, Benjamin Nguyende, Guillaume Scerri, Inf. Syst., 80, 13-35 (2019) https://doi.org/10.1016/j.is.2018.09.002

12. Dz. Faizrakhmanov, A. Zakirova, G. Klychova, A. Yusupova, A. Klychova, E3S Web of Conferences 91, 06004 (2019) doi.org/10.1051/e3sconf/20199106004

13. A. Klychova, G. Klychova1, A. Zakirova, R. Sungatullina, K. Mukhamedzyanov and E. Philippova, E3S Web Conf. 11002072 (2019) DOI: https://doi.org/10.1051/e3sconf/201911002072

14. Karen Maas, Stefan Schaltegger, Nathalie Crutzen, J. CP, 136， ， 1-248 (2016) https://doi.org/10.1016/j.jclepro.2016.05.008

15. A. Zakirova, G. Klychova, O. Doroshina, I. Safiullin, R. Nurieva and Z. Zalilova, E3S Web of Conf. 110, 14, 02073 (2019) DOI: https://doi.org/10.1051/e3sconf/201911002073

16. Odysseas Pavlatosa, Hara Kostakis, J. EA, 18, e00106 (2018) https://doi.org/10.1016/j.jeca.2018.e00106

17. Janvan Heldena, Shahzad Uddin, CPA, 41, 34-62 (2016) https://doi.org/10.1016/j.cpa.2016.01.001

18. Martin R.W. Hiebl, MAR, 38, 22-38 (2018) https://doi.org/10.1016/j.mar.2017.03.003

19. G. Klychova, A. Zakirova, R. Mannapova, K. Pinina and Y. Ryazanova, E3S Web of Conf. 110, 10, 02075 (2019) DOI: https://doi.org/10.1051/e3sconf/201911002075

20. SanjayaMayadunne, SungjunePark, Inter. Jour. of PE,182, 519-530 (2016) https://doi.org/10.1016/j.ijpe.2016.09.018

21. G.S. Klychova, A.R. Zakirova, E.R. Kamilova, IBM, 10, 5254 (2016) DOI: 10.3923 / ibm.2016.5254.5260 